\title{
INCONSTANT BONES OF THE HUMAN SKULLS FROM SCYTHIANS GRAVE FIELD NEAR KOLOMAK VILLAGE
}

\author{
Sherstyuk Sergey, Polstyanoi Andrii, Prokhorchuk Roksolana
}

Mail for correspondence: andreypolstyanoj@karazin.ua

\begin{abstract}
Summary: The research of the features of variant anatomy, as an integral part of paleoanthropological exploration, is an extremely important source of additional information about the anatomical structure of humans. Patterns of variability and frequency distribution of discrete variational features in variant anatomy remain important. Cranioscopic variational (or non-metric) features - anatomical variations in the skeleton structure, registered according to the "presence-absence" principle, are an important source of information in studying the origin and ethnogenetic relationships of paleopopulations. These features include inconstant (additional) skull bones. By modern classification, there are three types of inconstant bones of the human skull: wormian (sutural) bones, fontanelle bones and insular bones. They have various causes: genetic factors, chronic high intracranial pressure, skull deformation, disturbances of the skull symmetry, different pathological processes, etc. The purpose of the work was to research the variant anatomy of inconstant bones of the human skull. The objective to research is the variant anatomy of inconstant skull bones of the human on the anthropological materials from the Scythian grave field. It located near Kolomak village in the Kharkiv region and dates back to IX - IV century BC. The 88 skulls of adult persons has been researched. The inconstant additional bones of skull were present in the structures of 16 skulls out of $88(18.1 \%)$. Results. The sutural (wormian) bones were present in 12 skulls (13.6\%), fontanelle bones - in 6 skulls (6.8\%), insular bones were absent. In the anatomical structures of 10 skulls (11.4\%) were only wormian bones, in 4 skulls (4.5\%) were only fontanelle bones, in the structures of 2 skulls (2.3\%) were combination of sutural and fontanelle additional bones. Often the inconstant bones were located in several sutures at the same time. The most common sutural bones were lambdoid suture bones - 9 skulls (10.2\%). The inconstant bones of the coronal suture and sagittal suture were found in 2 skulls (2.3\%). The additional bones of the occipital-mastoid, parietal-mastoid and squamosal sutures were absent on the examined osteological materials. The fontanelle bones most often located at the place of the occipital fontanellele and they were present in 4 skulls (4.5\%). The additional fontanelle bones of the mastoid fontanellele were found in 2 skulls $(2.3 \%)$. The frontal fontanelle bone was in 1 skull (1.1\%). The additional fontanelle bones of the sphenoid fontanellele and interparietal bones were not found in the researched skulls. Conclusion. It is interesting to consider the case of combination in one skull a large inconstant bone of the sagittal suture with complete metopic (frontal) suture and occipital bone of sufficiently large size. The results of the research expanded and updated the existing data on the variant anatomy of inconstant cranial bones. Also, the results obtained maybe required in the further research of individual variability in the structure of the human's skull.
\end{abstract}

Key words: inconstant bones of the skull, wormian bones, sutural bones, fontanelle bones, human variant anatomy, paleoanthropology

\section{Information about author}

Sherstyuk Sergey., MD, PhD, Assoc.

Prof., The Head of the Department of

Human Anatomy of V. N. Karazin Kharkiv

National University, Svobody Sq, 6,

Kharkiv, Ukraine, 61022

e-mail: anatomy@karazin.ua

https://orcid.org/0000-0001-6062-7962

Polstyanoi Andrii, Assistant of Department of Human Anatomy of V. N. Karazin Kharkiv National University, Svobody Sq, 6, Kharkiv, Ukraine, 61022 e-mail: andreypolstyanoj@karazin.ua https://orcid.org/0000-0002-6513-1533
Prokhorchuk Roksolana, Assistant of Department of Human Anatomy of V. N. Karazin Kharkiv National University, Svobody Sq, 6, Kharkiv, Ukraine, 61022 e-mail: prokhorchuk@karazin.ua https://orcid.org/0000-0002-7194-5584
Introduction. In recent years, there have been some changes in trends in domestic and foreign anthropology. Currently, the importance of variant anatomy is increasing. However, the research of bone remains of modern and fossil human populations has always been of great importance for anthropological science, contributing to the research of its various directions. The research of the relationship between the 
variability of osteological features allows us to characterize the structural type of a group of individuals, as well as to compare intergroup and intragroup variability.

The research of the variant anatomy and features of individual anatomical formations, their topography from the standpoint of a macroscopic point of view is also considered relevant. The regularities of variability and frequency distribution of variational features in the context of variant anatomy remain are important. Therefore, the research of the features of variant anatomy, as an integral part of paleoanthropological research, is an extremely important source of additional information about the anatomical structure of humans [4].

In modern paleoanthropological research, variational features on skeletal bones play a significant role as an additional source of information. Variational features are nonmetric, qualitative features, which determined by the principle of "presence" or "absence". In anatomy in general, and in craniology in particular, this term has become widespread relatively recently recently in the last quarter of the twentieth century. Prior to that time, many variants of the anatomical structure in literary publications were usually called "anomalies".

Cranioscopic discrete variation, or nonmetric features, which are anatomical variations in the structure of the skull are an important source of information in studying the origin and ethnogenetic relationships of paleopopulations.

In modern historical and anthropological science the research of variational features on craniological material is widespread. Variational features on the skull are understood as variations in its anatomical structure, which are manifested in the form of inconstant bones [4].

One of these features is the inconstant bones of the skull, usually located between the normal permanent bones of the human skull $[5,9,11]$. According to the classification by Speransky V. and Zaichenko A. (1980) inconstant skull bones are divided into 3 groups: sutural or wormian (ossa suturalia), fontanelle (ossa fonticulorum), insular (ossa insularia). The names of the groups reflect their localization in the anatomical structure of the skull [11].

Wormian bones or sutural bones are accessory small bones which occur accidentally or intercalated between or near cranial sutures isolated from normal ossification center of skull [7].

The fontanelle bones located between the calvarial bones in the fontanelles and border on three or more permanent skull bones. These bones are derived from accessory ossification centers [8]. The fontanelle bones were first discovered in man in the sixteenth century by the physician Paracelsus, who gave them the name "ossiculum anti-epilepticum," believing them to be a remedy for epilepsy. Since that time various names have been given to this bone type by different researchers and authors: they have been often termed "os bregmaticum" and many other names. The insular bones are located inside the permanent bones of the skull [11].

Inconstant bones of the skull are develop in utero, and sometimes after birth. It is unclear at this time exactly how they are formed, although genetic as well as environmental factors have been proposed [1]. The appearance of these bones is due to a number of reasons: genetic factors, deformation and changes of symmetry in the anatomical structure of the skull, osteogenesis imperfecta, chronic increase in intracranial pressure, various pathological processes, can be combined with developmental abnormalities of the brain [9, 10, 11]. However, most often this phenomenon is associated with abnormalities in the manifestation of genetic differences at the phenotype level $[10,11]$.

At the same time, explorations by various authors show that the processes that lead to the appearance of inconstant bones, and the processes under the influence of which the skull is formed, are independent of each other [3]. The occurrence of fontanelles bone not connecting with the occurrence of wormian bones (except for weak connection anterior fontanelle bone and coronal suture bone), which may indicate the influence of various factors on their appearance [11]. Clinically 
inconstant bones are used as one of the markers in the diagnoses of many autosomal dominant genetic disorders, such as, craniosynostosis and osteogenesis imperfect [1].

According to the literature, additional bones of the human skull with various localization in different populations occur with a frequency of 20-67\% [2, 6, 7, 11]. Some authors note gender differences in the frequency of inconstant cranial bones, while other authors don't note such differences. Additional bones are most common in structure of the brachycranial skull type. At the same time, some authors, such as $\mathrm{H}$. Grimme, refute the relationship between the shape of the skull and the frequency with which additional bones occur [11].

The purpose of the work: exploration the variant anatomy of inconstant bones of the human skull on the anthropological materials from Scythians grave field near Kolomak village.

Materials and methods. This observational study was carried out on 88 adult skulls with different preservation (in most cases, only the neurocranium of them preserved, in some cases the skull base was damaged), which were extracted in the $\mathrm{XX}$ century from the grave field near Koloamak village and currently stored in osteological collection of the Department of Human Anatomy of the V. N. Karazin Kharkiv National University. The settlement and gravefield "Grashkivsky" of the IX century IV century BC near the village of Kolomak, Kharkiv region of Ukraine - archeological monument (Early Iron Age, Scythian culture). It located $0.5 \mathrm{~km}$. to the north-western part of the former Grishkovo village, which is currently the south-western outskirts of Kolomak village.
The basis of the research methodology is the identification and registration of variational features (presence of different types of additional skull bones) with subsequent statistical processing of the results to determine the frequency of these traits in the population.

All researches were performed in accordance with the Council of Europe Convention on the Protection of Human Rights and Human Dignity in the Application of Biology and Medicine: Convention on Human Rights and Biomedicine (ETS № 164) of 04.04.1997, and the Declaration of Helsinki World Medical Association (2008).

Results. In the our research the inconstant skull bones were present in the anatomical structure of 16 skulls out of 88 , which is $18.1 \%$ of the total.

The wormian (sutural) bones were present in structure of 12 skulls (13.6\%), fontanelle bones - in 6 skulls $(6.8 \%)$, insular bones were absent. Often inconstant bones in the skulls were located in several sutures at the same time.

The most common wormian inconstant bones were lambdoid suture bones. They were found in 9 skulls $(10.2 \%)$. In most cases, the lambdoid suture contained from 1 to 5 bones. Multiple lambdoid wormian bones have been found only in structure of the 1 skull $(1.1 \%)$, although statistics show that they are the most common variant of additional human skull bones in other populations.

The wormian bones of the lambdoid suture on the researched skulls were mostly partially elongated, crest-shaped, less often irregular or rounded. In the majority of cases, their size was $9-18 \mathrm{~mm}$, but smaller bones were also found. The location of these additional bones in 5 skulls $(5.7 \%)$ was bilateral, in 3 skulls $(3.4 \%)$ - only on the right side, in 1 skull $(1.1 \%)-$ on the left side (Fig. 1, Fig. 2). 
Actual problems of modern medicine. Issue 6, 2020

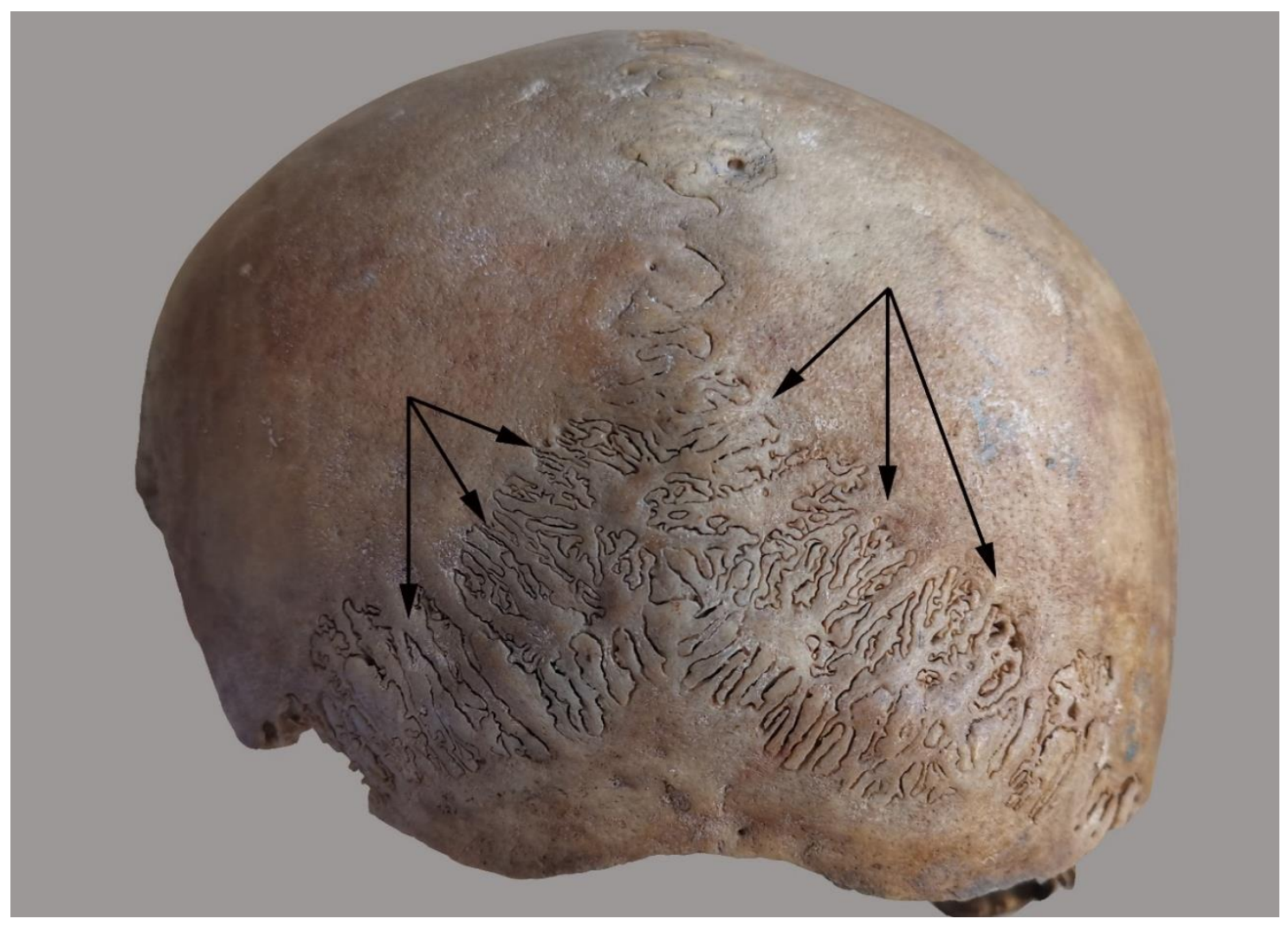

Fig. 1. Multiple inconstant wormian bones of the lambdoid suture

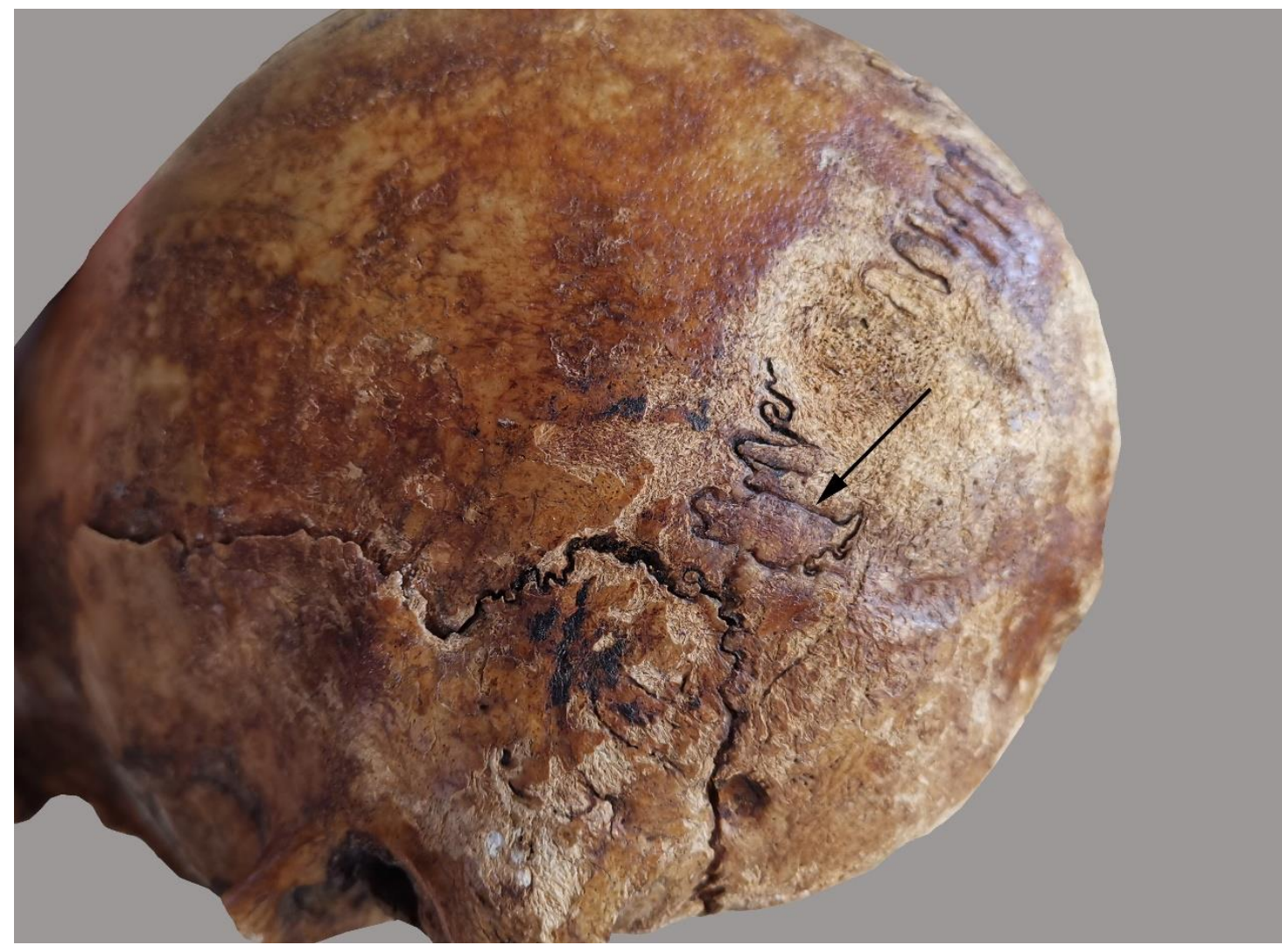

Fig. 2. Single inconstant wormian bone in left half of the lambdoid suture 
Sagittal suture wormian bones were found in structures of the 2 skulls $(2.3 \%)$. In all cases, these were single elongated bones measuring $10 \times 17 \mathrm{~mm}$ and $16 \times 33 \mathrm{~mm}$.
One of the skulls had a combination of a lost wormian bone of elongated shape, located in front of the sagittal suture with a complete metopic (frontal) suture and lost occipital fontanelle bone (Fig. 3).

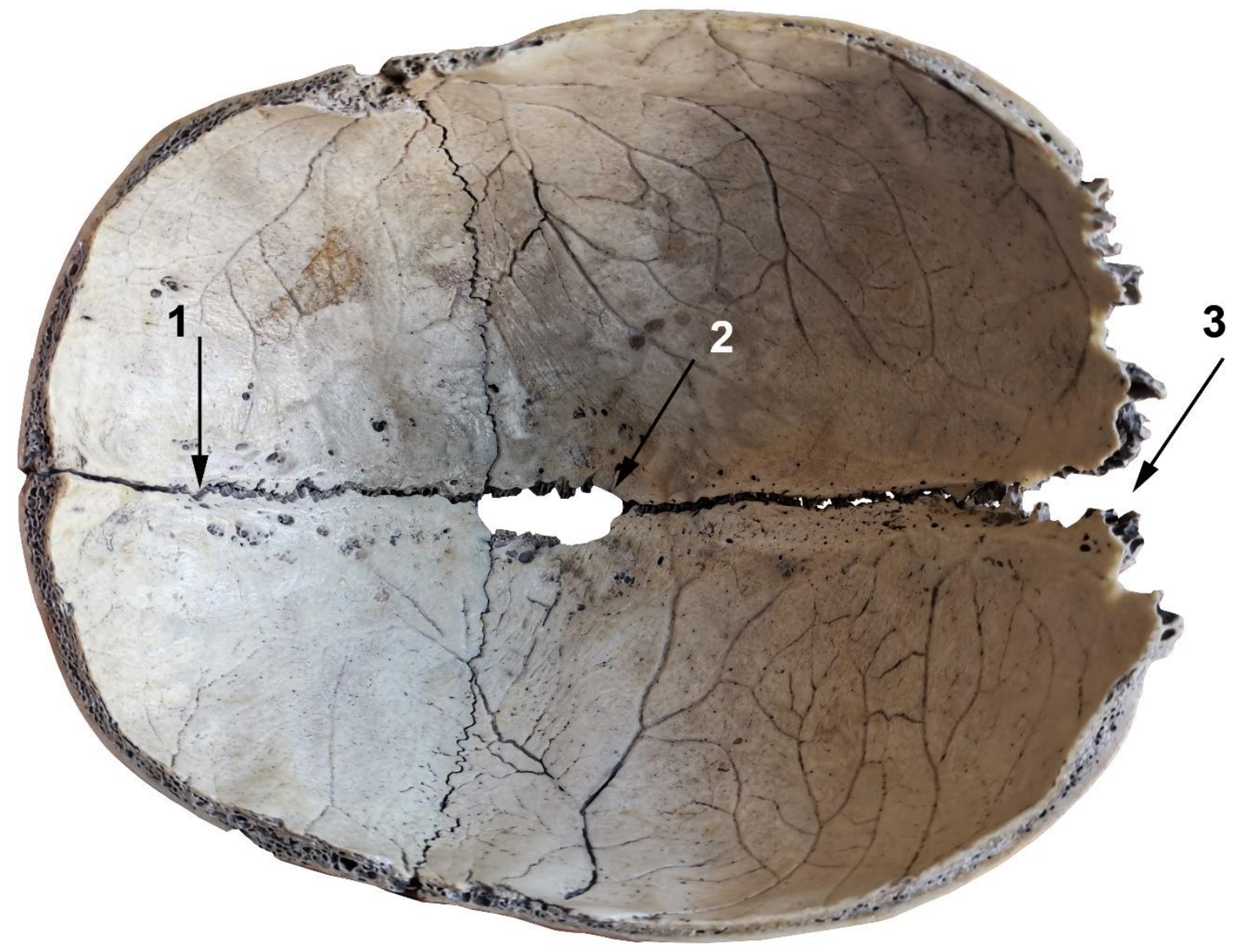

Fig. 3. The combination of a lost wormian bone in the sagittal suture (2) with complete metopic (frontal) suture (1) and lost occipital fontanelle bone (3). View from the side of the cranial cavity

The bones of the coronal suture were in the structure of 2 skulls $(2.3 \%)$. In the first case on each side of the suture was placed a single bone. The left bone was rectangular in shape, with size $11 \times 16 \mathrm{~mm}$. The left bone characterized by an elongated shape of an irregular rhombus, it size $-6 \times 12 \mathrm{~mm}$. In the second case, two small bones with an oval elongated shape and size $3 \times 5 \mathrm{~mm}$ and $4 \times 6 \mathrm{~mm}$ were placed in the right half of the suture.

The bones of the parietal-mastoid suture were present in 1 skull $(1.1 \%)$. The location of the bones was one-sided in the right suture. Two bones with size $2 \times 5 \mathrm{~mm}$ and $3 \times 10 \mathrm{~mm}$ have an elongated triangular irregular shape.
The bones of the occipital-mastoid, parietal-mastoid and squamosal sutures were absent on the examined osteological materials.

The fontanelle bones in the researched skulls were most often located at the place of the occipital fontanellele.

The occipital fontanelle bones were present in 4 skulls $(4.5 \%)$. These bones were single, triangular, quadrangular or irregular in shape. Their sizes from $8 \times 19 \mathrm{~mm}$ to $25 \times 36 \mathrm{~mm}$. One of the skulls had double occipital fontanelle bones with total size $19 \times 20 \mathrm{~mm}$.

The fontanelle bones of the mastoid fontanellele were found in structure of the 2 skulls $(2.3 \%)$. They were with elongated or irregular shape. The sizes of the bones were 
8-16 $\mathrm{mm}$. The location of these inconstant bones was bilateral in both cases.

The frontal fontanelle bone was in 1 skull $(1.1 \%)$. It was a large additional bone $13 \times 22$ $\mathrm{mm}$, with an elongated shape in the anteriorposterior direction close to the shape of a rectangle with uneven strongly "wavy" borders.

The additional fontanelle bones of the sphenoid fontanellele were not found in the researched skulls.

The interparietal bones also were not presented on the researched osteological materials.

Conclusion. By reseaching anthropological material from the grave field near the Kolomak village researched the anatomical variability of additional skull bones a separate Scythian population. In general, according to the results of the research, inconstant skull bones were present in the anatomical structure of 16 skulls out of 88 , which is $18.1 \%$ of the total. In the anatomical structure of 10 skulls $(11.4 \%)$ were only wormian bones, in 4 skulls $(4.5 \%)$ were only fontanelle bones and in the structure of 2 skulls $(2.3 \%)$ was a combination of sutural and fontanelle additional bones. Insular bones in the researched osteological material are absent. Occasionally, inconstant sutural bones were localized in several sutures at once, or combined with the fontanelle bones.

Literature data show that inconstant skull bones among representatives of various modern populations occur with a frequency of 20 to $67 \%$. Thus, the results of the research indicate that the skull with single inconstant sutural bones and additional fontanelle bones are not common variant of anatomical structure among the osteological materials from the Scythian grave field near the Kolomak village. Skulls with numerous inconstant bones are also a rare variant of the structure.

An interesting finding was the case of combination in one of the skulls of a large sagittal suture additional bone with other discrete variational features in the form of an existing complete metopic (frontal) suture (sutura frontalis s. sutura metopica) and occipital fontanelle bone. In our opinion in this case the formation of metopic suture and two large inconstant bones has been frequently associated with a non-syndromic isolated craniosynostosis. It has been often related to a chromic increase in the intracranial pressure and commonly when a midline suture (metopic or sagittal) is involved. In this case, the intracranial pressure grow gradually, occurring with the growth of the individual in childhood. In additional, the initial area in the sagittal synostosis is crucial for the direction of the increased intracranial pressure from the growing structures of the brain, anteriorly or posteriorly along the midline, coinciding with the projection of the sagittal suture. This causes the sutural widening which possibly trigger the metopic suture formation, bone formation in the sagittal suture and posterior fontanelles.

The results of the completed osteological research will expand and update the existing data on the variant anatomy of inconstant cranial bones. Further research of this variational feature and its variability on craniological materials from other osteological collections will allow to more fully characterize the structural type of a group of individuals, as well as to compare intergroup and intragroup variability, in particular among anthropological materials from different Scythian grave fields in Eastern Ukraine.

The use of data about local Scythian groups will bring us closer to understanding the origin of the Scythians, as well as the factors that determined anthropological differentiation within the Scythian population. If the main factor of this differentiation was microevolutionary, then it is unlikely to expect a special closeness of individual Scythian populations to nonscythian groups, since microevolution (including brachycephalization, gracilization, and random processes) theoretically cannot lead to convergent similarity of unrelated groups along the entire complex of characters. If such a similarity is nevertheless observed, then it, as a rule, indicates a relationship. 
Also, the restoration of morphological characteristics of osteometric features at the individual level has practical significance in archaeoanthropological reconstruction.

\section{References}

1. Bellary, SS, Steinberg, A, Mirzayan, N, Shirak, M, Tubbs, RS, et al. Wormian bones: a review. Clin Anat. 2013; 26(8):922-27. DOI: 10.1002/ca.22262

2. Cirpan S, Aksu F, Mas N. The incidence and topographic distribution of sutures including wormian bones in human skulls. J Craniofac Surg. 2015;26:1687-90. DOI: 10.1097/SCS.0000000000001933

3. Ghosh SK, Biswas S, Sharma S, Chakraborty S. An anatomical study of wormian bones from the eastern part of India: Is genetic influence a primary determinant of their morphogenesis? Anat Sci Int. 2017;92:373-82. DOI: 10.1007/s12565-016-0342-1

4. Hanihara T, Ishida H, Dodo Y. Characterization of Biological Diversity Through Analysis of Discrete Cranial Traits. Am J Phys Anthropol. 2003;121:241-51. DOI: 10.1002/ajpa.10233

5. Himabindu A, Rao BN. An insight into Wormian bones. International Journal of Scientific Research and Engineering Studies. 2015;2(6):26-8. Available from:https://www.researchgate.net/publication/279916562_an insight_into_wormian_bones_ahimabindubnarasingarao

6. Natsis K, Piagkou M, Lazaridis N, Anastasopoulos N, Nousios G, et al. Incidence, number and topography of wormian bones in Greek adult dry skulls. Folia Morphol (Praha). 2019;78:359-70. DOI: 10.4067/S0717-95022020000100069

7. Kiliç-Safak N, Taskin RG, Yücel AH. Morphologic and Morphometric Evaluation of the Wormian Bones. Int $\mathrm{J}$ Morphol. 2020;38(1):69-73. DOI:10.4067/S071795022020000100069

8. Nikolova SY, Toneva DH. Incidences of anterior fontanelle bone in cranial series from Bulgaria. J Biosci Biotechnol. 2014;special edition:145-47. http://www.jbb.uniplovdiv.bg/documents/27807/728057/SE-2014-145-147.pdf

9. Samson TD, Beals SP, Rekate HL. Massive wormian bone at the cranial apex: identification, correction and outcome. J Craniofac Surg. 2008;19(1):96-100. DOI:10.1097/scs.0b013e31815c94ad

10. Semler O, Cheung MS, Glorieux FH, Rauch F. Wormian bones in osteogenesis imperfecta: correlation to clinical findings and genotype. Am J Med Genet A. 2010;152A(7):1681-87. DOI: 10.1002/ajmg.a.33448.

11. Zaychenko AA, Zhurkin KI. Bones of sutures and fontanelleles of the human cranial [in Russian]. Saratov journal of medical scientific research. 2017;13(2):209-12. Available from:http://ssmj.ru/2017/2/209.

\title{
НЕПОСТІЙНІ КІСТКИ НА ЧЕРЕПАХ 3 СКІФСЬКОГО МОГИЛЬНИКА БІЛЯ с. КОЛОМАК
}

\author{
Шерстюк С. О., Полстяной А. О., Прохорчук Р. М.
}

Пошта для листування: andreypolstyanoj@karazin.ua

\begin{abstract}
Резюме: Дослідження особливостей варіантної анатомії людини, як важнлвої та невід'ємної частини палеоантропологічних досліджень, є ваюжлвим джсерелом додаткової інформамиї про особливості анатомічної будови людини. Краніоскопічні (дискретні варіачійні, або неметричні) ознаки, щчо являють собою анатомічні варіачії в будові черепа, реєструються за принципом «присутність-відсутність», є ваљсливи джсерелом інформації при вивченні походження і етногенетичних зв'язків палеопопулячій. До цฺих ознак відносяться втому числі непостійній (додаткові) кістки черепа. За сучасною класифікаиією прийнято виділяти З головні типи непостійних кісток черепа: шовні, тім'ячкові та островиеві кістки. Метою роботи було проведення дослідження питань варіантної анатомії непостійних кісток на черепах людей. Матеріали та методи. Була досліджена варіантна анатомія непостійни кісток на антропологічних матеріалах черепів з скіфського могильника поблизу села Коломак на Харківщині, шчо датується IX - IV cтоліттям до н.е. Було досліджсено 88 черепів дорослих людей. Результати. Непостійні додаткові кістки були присутні в будові 16 черепів, що становить 18,1\% від загальної кількості. Шовні кістки були в 12 черепах (13,6\%), тім'ячкові - у 6 черепах (6,8\%), острівцеві кістки були відсутні. У частині випадків непостійні кістки розтаповувались одночасно в декількох швах. Цікаво відмітити випадок поєднання в одному з черепів великої додаткової кістки стрілового шва з повним метопічним швом та додатковою кісткою потиличного тім'ячка. Згідно літературних даних додаткові кістки черепа зустрічаються в різни популячіях з частотою від 20 до 67\%. Висновки. Таким чином, результати дослідження вказують на те, щуо даний тип дискретно-варіаційних ознак є рідкісним варіантом анатомічної будови серед досліджених остеологічних матеріалів. Результати дослідження розимюють та доповнюють наявні дані про варіантної анатоміі непостійних кісток черепа. Подальші дослідження краніологічних матеріалів дозволять більи повно та дослідити порівнювальнувнутрішньогрупову та міжсгрупову мінливість.
\end{abstract}

Ключові слова: непостійні кістки черепа, шовні кістки, тім’ячкові кістки, варіантна анатомія людини, палеоантропологія

\footnotetext{
Інформація про авторів

Шерстюк Сергій Олексійович,

людини Харківського національного

майдан Свободи, 6, Харків, Україна, д. мед. н., проф., зав. кафедри анатомії університету імені В. Н. Каразіна, 
Actual problems of modern medicine. Issue 6, 2020

e-mail: anatomy@karazin.ua https://orcid.org/0000-0001-6062-7962

Полстяной Андрій Олександрович, асистент кафедри анатомії людини Харківського університету імені В. Н. Каразіна, майдан Свободи, 6, Харків, Україна, 61022

e-mail: andreypolstyanoj@ karazin.ua https://orcid.org/0000-0002-6513-1533

Прохорчук Роксолана Миколаївна, асистент кафедри анатомії людини
Харківського національного університету імені В. Н. Каразіна, майдан Свободи, 6, Харків, Україна, 61022

e-mail: prokhorchuk@karazin.ua https://orcid.org/0000-0002-7194-5584

\title{
НЕПОСТОЯННЫЕ КОСТИ НА ЧЕРЕПАХ СКИФСКОГО МОГИЛЬНИКА ОКОЛО с. КОЛОМАК
}

\author{
Шерстюк С. А., Полстяной А. А., Прохорчук Р. Н.
}

Пошта для листування: andreypolstyanoj @karazin.ua

Резюме. Исследования особенностей вариантной анатомии человека, как важная и неотъемлемая части палеоантропологических исследований, являются источником дополнительной информации об особенностях строения человека. Краниоскопические (дискретные вариационные, или неметрические) признаки, представляющие анатомические вариации в строении черепа, регистрируемые по принципу «присутствие-отсутствие», являются важным источником информации при изучении происхождения и этногенетических связей палеопопуляций. Одним из данных признаков являются непостоянные или добавочные кости черепа. Согласно современной классификации, выделяют три главных типа непостоянных костей черепа: шовные, родничковые и островковые кости. Целью работы было исследование особенностей непостоянных костей на черепах людей. Материалы и методы. Была изучена вариантная анатомия непостоянных костей на антропологических материалах черепов из скифского могильника вблизи села Коломак в Харьковской области, датируемого IX - IV веком до н.э. Было исследовано 88 черепов взрослых людей. Непостоянные дополнительные кости присутствовали 8 строении 16 черепов, что составляет 18,1\% от общего количества. Результаты. Шовные кости были в 12 черепах $(13,6 \%)$, родничковые - в 6 черепах (6,8\%), островковые кости не были обнаружены. В ряде случав непостоянные кости располагались одновременно в нескольких швам. Интересным является случай сочетания в одном из черепов крупной добавочной кости сагиттального шва с полным метопическим швом и дополнительной костью затылочного родничка. Согласно литературным данным, добавочные кости черепа встречаются в различных популяциях с частотой 20-67\%. Выводы. Таким образом, результаты исследования указывают на то, что данный тип вариационно-дискретных признаков является редким вариантом строения черепа среди исследованных остеологических материалов. Результаты исследования в значительной степени дополняют и расширяют существующие данные об особенностях вариантной анатомии добавочных костей черепа. Дальнейшие исследования краниологичних материалов могут позволить изучить сравнительную внутригрупповую и межгрупповую изменчивость

Ключевые слова: непостоянные кости черепа, шовные кости, родничковые кости, вариантная анатомия человека, палеоантропология

\section{Информация об авторах}

Шерстюк Сергей Алексеевич, д. мед. н., проф., зав. кафедрой анатомии человека Харьковского национального университета имени В.Н. Каразина, пл. Свободы, 6, Харьков, Украина, 61022 e-mail: anatomy@karazin.ua https://orcid.org/0000-0001-6062-7962
Полстяной Андрей Александрович, ассистент кафедры анатомии человека Харьковского национального университета имени В. Н. Каразина, пл. Свободы, 6, Харьков, Украина, 61022 e-mail: andreypolstyanoj@karazin.ua https://orcid.org/0000-0002-6513-1533
Прохорчук Роксолана Николаевна, ассистент кафедры анатомии человека Харьковского национального университета имени В. Н. Каразина, пл. Свободы, 6, Харьков, Украина, 61022 e-mail: prokhorchuk@karazin.ua https://orcid.org/0000-0002-7194-5584

Conflicts of interest: author has no conflict of interest to declare.

Конфлікт інтересів: відсутній.

Конфликт интересов: отсутствует. 